sleeping occupants of the bedroom. Its capacity to resist starvation is legendary, but it has few other outstanding qualities (apart from one of the most peculiar methods of copulation in the insect world)... but I digress. Someone at least appreciated its dogged determination to seek out its host when writing the following:

The butterfly has wings of gold,

The firefly wings of flame;

The bed bug has no wings at all,

But he gets there just the same. ${ }^{12}$

1 Mellanby K. The transmission of scabies. $B M \mathcal{F} 1941$;ii:405-6.

2 Mellanby K. Human guinea pigs. London: Gollancz, 1945.
3 P R M Guy's acarus. Transactions of the St Fohn's Hospital Dermatological Society 1972;58:113.

4 Kingsley J, ed. The poems and songs of Robert Burns. Vol 1. Oxford: Clarendon, 1968:193-4.

5 Stevenson B. Stevenson's book of quotations. 10th ed. London: Cassell, 1967: $1171,679$.

6 Bottomley G. The elder woman's songs. From "King Lear's Wife." In: Poems of thirty years. London: Constable, 1925:106.

7 Swift J. On poetry: a rapsody. In: Davis H, ed. Swift: poetical works. London: Oxford University Press, 1967:578.

8 Donne J. The Flea. In: Hayward J, ed. Fohn Donne: poetry. London: Penguin, 1986:48.

9 Lehane B. The compleat flea. London: John Murray, 1969:94, 37, 30

10 Flighty fleas. In: Silcock A. Verse and worse. London: Faber and Faber, 1969:242.

11 Milligan S. Lady B's Fleas. In: Patten B, ed. The Puffin book of twentiethcentury children's verse. London: Penguin, 1991:162.

12 The terror by night. In: Shrewsbury JFD. The plague of the Philistines. London: Gollancz, 1964:146.

\title{
Modifying chickenpox
}

\section{Eric Pennington, Sheila Pennington}

It is commonly accepted folklore in general practice that a patient with chickenpox, kept cool, has less itching. Nevertheless, skin temperature has never been shown to have any objective effect on the severity of the illness in children. In most people the typical distribution of the rash coincides with the part of the body that is usually the warmest: the head, trunk, and proximal limbs. Theoretical consideration might suggest, therefore, that the number of spots in chickenpox is related to skin temperature. Chickenpox occurs in sporadic outbreaks, usually in small children, so it is difficult to design a controlled experiment to assess this theory. Our report shows, in a single individual, that cutaneous temperature affects the severity of chickenpox.

\section{Method and results}

On diagnosis of chickenpox a garment was constructed consisting of a woollen jumper with one arm pulled through the other, forming a double thickness half jumper. This was sewn to a long sleeved shirt (figure). Thus the right half of the torso had two layers of jumper plus a shirt and the left had only a shirt. A similar pyjama top was constructed. The patient accepted these garments and wore them throughout the experiment.

The attack of chickenpox was mild, and spots erupted over only two days. The number of spots on each side of the midline of the area covered by the trial garment was counted at the end of each day. On the first day there were 11 spots on the left (cool) side and 27 on the right (warm) side. On the second and third days the numbers were 20 and 34, and on the fourth day there were 18 spots on the cool side and 34 on the warm side.

The results confirm, in a single subject, our clinical impression that reducing cutaneous temperature reduces the number of spots in cases of chickenpox.

\section{Moseley, Birmingham B13.9YD \\ Eric Pennington, DRCOG, general practitioner Sheila Pennington, DRCOG, general practitioner}

\section{Correspondence to:}

Dr E Pennington.

BMF 1991;303:1614

\section{Comment}

We noticed several years ago that children with chickenpox whose homes were kept at a high temperature, or who were wrapped up warm when ill, seemed to have more spots. This prospective study confirms our suspicion that it is possible to modify the course of chickenpox simply by controlling cutaneous temperature. A chance observation provides a possible mechanism for this finding. Chickenpox occurred in a patient while a laparotomy wound was healing and a Koebner phenomenon was noted of clustering of

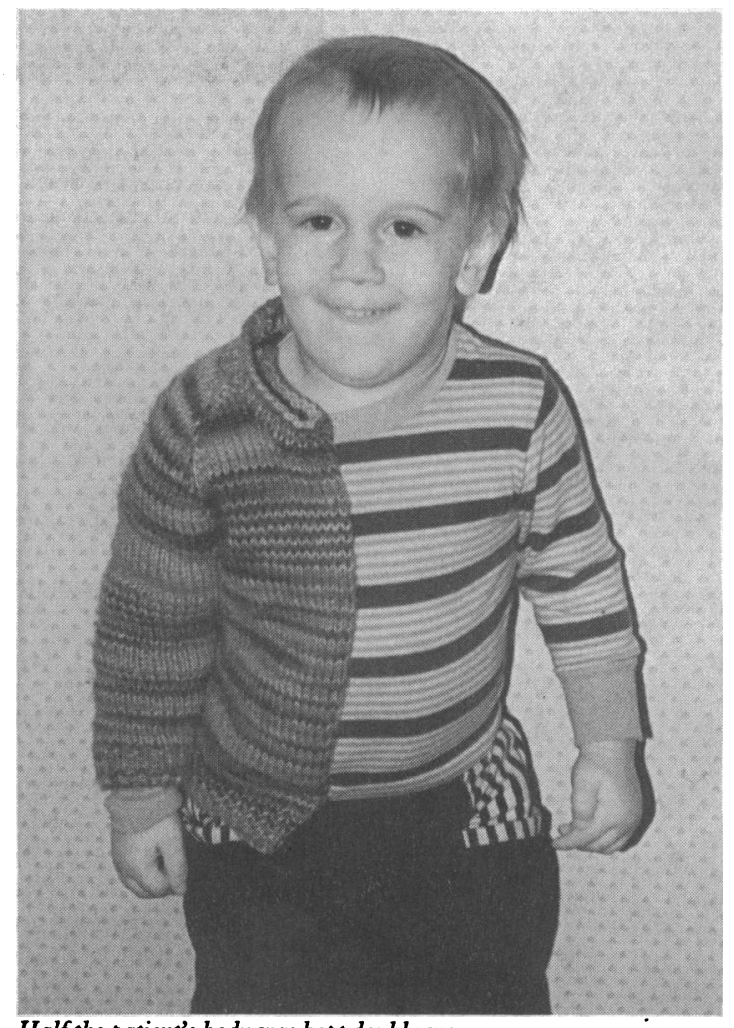

Half the patient's body was kept doubly warm

the chickenpox around the incision area. Increased cutaneous blood flow and raised skin temperature are common to both observations.

One serious implication of this study is for research on the efficacy of antiviral agents against chickenpox. These studies comparing a drug against placebo often quote the extent of the rash as one index of severity. They may need to include skin temperature as a variable if meaningful results are to be obtained. Recent studies do not seem to have done so. ${ }^{2-4}$

Skin temperature seems to have a major influence on the severity of rash in chickenpox. This can be reduced by light clothing and turning down the central heating.

1 Healsmith MF, Berth-Jones J, Graham-Brown RAC. Koebner phenomenon in varicella. $B M \mathcal{F}$ 1990;301:1286.

2 Balfour HH, Kelly JM, Suares CS, Heusser RC, Englund JA, Crane DD, et al. Acyclovir treatment of varicella in otherwise healthy children. $\mathcal{J}$ Pediatr 1990;116:633-9.

3 Boyd E, Walker E. Use of acyclovir to treat chickenpox in pregnancy. $B M \mathcal{J}$ 1988;296:393-4.

4 Peterslund NA. Management of varicella zoster infections in immunocompeten hosts. Am f Med 1988;85(suppl 2a):74-8. 